See discussions, stats, and author profiles for this publication at: https://www.researchgate.net/publication/340297763

\title{
Linking Ethical Leadership and Ethical Climate to Employees' Ethical Behavior: The Moderating Role of Person-Organization Fit
}

Article in Personnel Review · March 2020

DOl: 10.1108/PR-09-2019-0522

\section{CITATIONS}

5 authors, including:

Hussam Al Halbusi

Sultan Qaboos University

30 PUBLICATIONS 73 CITATIONS

SEE PROFILE

T. Ramayah

Universiti Sains Malaysia

634 PUBLICATIONS 16,078 CITATIONS

SEE PROFILE
READS

914

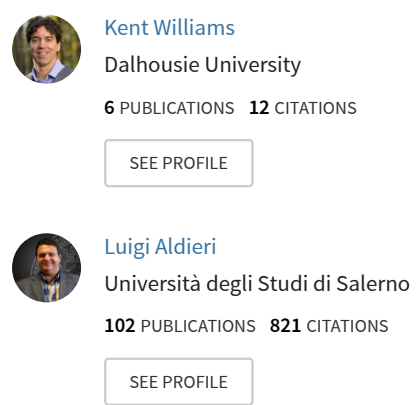

Some of the authors of this publication are also working on these related projects:

Project Empirical analysis of the role of Patents in the innovation process of international firms View project

BIOSCIENCES AND BIOTECHNOLOGYM⿻上丨 View project 


\title{
Linking ethical leadership and ethical climate to employees' ethical behavior: the moderating role of person-organization fit
}

\author{
Hussam Al Halbusi \\ Business Policy and Strategy, Universiti Malaya, Kuala Lumpur, Malaysia \\ Kent A. Williams \\ Faculty of Management, Dalhousie University, Halifax, Canada \\ Thurasamy Ramayah \\ Universiti Sains Malaysia, Penang, Malaysia; \\ Internet Innovation Research Center, Minjiang University, China and \\ Universiti Tunku Abdul Rahman (UTAR), Malaysia, and \\ Luigi Aldieri and Concetto Paolo Vinci \\ University of Salerno, Fisciano, Italy
}

\begin{abstract}
Purpose - With the growing demand for ethical standards in the prevailing business environment, ethical leadership has been under increasingly more focus. Based on the social exchange theory and social learning theory, this study scrutinized the impact of ethical leadership on the presentation of ethical conduct by employees through the ethical climate. Notably, this study scrutinised the moderating function of the personorganisation fit (P-O fit) in relation of ethical climate and the ethical conduct of employees.

Design/methodology/approach - To evaluate the research hypotheses, two-wave data were collected from 295 individuals who are currently employed in various Iraqi organizations (i.e. manufacturing, medical and insurance industries).

Findings - In line with the hypotheses, the outcomes from a sample of 295 workers working in different Iraqi entities exhibited a positive relation between the ethical behaviour of leaders and the ethical conduct of employees in the ethical climate. Moreover, it was observed that the P-O fit of employees moderated the relationship between ethical climate and the ethical conduct of employees such that the relationship was more robust for those with a high P-O fit in comparison to those with a low P-O fit.

Research limitations/implications - The primary limitation of this study is in the data, which was obtained from a single source. Although the study conducted two surveys and utilised a mediation and moderation variables model that was less likely to be influenced by common method bias (CMB) (Podsakoff et al., 2012), one cannot completely rule out $\mathrm{CMB}$. Apart from the potential effects of the $\mathrm{CMB}$, the consistency of the empirical findings could have also been compromised since self-reported data were utilised in measuring ethical behaviour, which can be a very complex and sensitive issue. For this reason, the social desirability response bias cannot be ruled out completely. When possible, future studies must gather data from multiple sources. Furthermore, supervisors must evaluate the ethical behaviour of employees. Another limitation was that the findings of this study were based on a sample in a Middle Eastern cultural context such as in Iraq. Perhaps, the particular cultural features of this context, which encompassed, among other things, a strong adherence to religious values (Moaddel, 2010), could have influenced the findings of this study. It is true that the effects of differences (P-O fit) are highly likely to replicate across cultural contexts (Triandis et al.,1988). However, it can be seen that further studies are needed to evaluate the context-sensitivity of these findings (Whetten, 2009) by analysing other cultures, where the importance of religiosity is on the decline (i.e. in Western countries, Ribberink et al., 2018) or where the cultural features are very much different from those that apply to Iraq. Lastly, other external factors were not taken into account by this study as it tried to explain ethical behaviour. Ethics is a highly complex subject and is influenced by numerous variables at the organisational, individual and external environment levels. Thus, caution must be observed when making inferences from the present study which, to a certain degree, offered a simplified version of ethical behaviour by
\end{abstract}

Funding: This work was not funded.

Received 27 September 2019 Revised 29 September 2019 22 November 2019

Accepted 29 March 2020
Linking ethical leadership and ethical climate 
concentrating on a few variables such as the Arab culture's traditional ideology, which dominates even science (Abu Khalil, 1992). In addition, there are the political conflicts in the Middle Eastern cultural context such as what is happening in Iraq (Harff, 2018). Thus, it is important to include such aspects in future researches.

Practical implications - In terms of management, the findings send a clear signal to those in the upper echelon that, without ignoring the issue of ethics in organizations, employees are a critical aspect to be taken into account to encourage ethical behaviour at the workplace. This study has important practical implications. First, this study determined that ethical leadership (here, of the supervisors) positively influences the behaviour of subordinates (refers to the supervisors here); this in turn further improves the ethical behaviour of employees. It is vital that managers or supervisors are motivated to practice ethical leadership because they directly influence the employees. It has been suggested that top managers, especially chief executive officers, have the ability to shape the ethical climate, which also influences the ethical behaviour of employees further. This study offered several feasible ways that managers can apply to achieve that. In particular, top managers may utilise the ethical climate as a way of communicating the ethical values that they have to their subordinates, thereby serving as a motivation for the subordinates to adopt an ethical behaviour. It was also suggested by this study that ethical climate and the P-O fit may, to some degree, substitute each other as they influence the ethical behaviour of employees. Therefore, firms that were identified to have a low level of ethical standards, practices, and policies, at least from the employees' perspective, are better poised to conduct ethical issues in order to construct the ethical behaviour of their subordinates. More importantly, it is highly essential that the value congruence between an organization and its followers be considered.

Social implications - This study highlighted the notion of ethics and how it's essential for society. Ethics refer to the norms, standards, and values that direct the behavior of an individual. Ethical behaviour is vital in society because we need to be treated with respect as human beings.

Originality/value - This study responds to recent calls for more research to identify factors which may strengthen or mitigate the influence ethical behavior in the workplace such as ethical leadership, ethical climate and Person-Organization.

Keywords Ethical leadership, Ethical climate, Person-organizationfit, Ethical behaviour, Social exchange theory, Social learning theory

Paper type Research paper

\section{Introduction}

Researchers, organizations, governments and practitioners have been under pressure due to incidents of ethical scandals in recent years (Manz et al., 2008; Mehta, 2003; Brown and Treviño, 2014; Treviño et al.,2014; AlHalbusi, et al.,2017). Due to ethical issues and concerns in corporations such as the National Irish Bank and Enron, researchers and analysts across the world have observed that people with compromised ethical behaviour are likely to focus on and achieve their personal goals and desires at the cost of organisations or corporations (Padilla et al., 2007; Schaubroeck et al., 2007). As highlighted by Treviño and Brown (2004), ethical and unethical behaviour have existed been int have been in existence since the beginning of human civilisation.

Practitioners and academicians have increasingly raised an important query linked with the role of ethical leadership (Brown and Trevino, 2006; Neubert et al., 2009; Mayer et al., 2009; Treviño et al., 2014). Leaders are bound to exhibit a high level of ethical behaviour and have the highest moral standards when it comes to actions, behaviour and decision-making. This is necessary so that they can set an ideal example for their followers or team members to emulate (Ofori, 2009). In earlier studies on ethical leadership, the significance of considering the role of ethical leadership was apparently specified to analyse the ethical behaviour of employees (Brown et al., 2005; Ofori, 2009; Newman et al., 2015; Neves et al., 2018; Al Halbusi et al., 2019b).

It has been thoroughly highlighted in the literature that an organisation's ethical atmosphere or climate has a substantial impact on the ethical behaviour of its employees (Luria and Yagil, 2008; Deshpande and Joseph, 2009; Treviño et al., 2014; Al Halbusi and Amir Hammad Hamid, 2018). There is considerable influence of the ethical climate of the organisation on the ethical behaviour of employees (Elçi and Alpkan, 2009; Engelbrecht et al., 2017; Aryati et al., 2018). Because subordinates perceive the existing ethical climate to impact organisational policies, procedures for decision-making and the payment system, they are likely to offer services and act well in the organisation when the ethical atmosphere in the organisation is strong (Weeks et al., 2004; Lu and Lin, 2014; Demirtas and Akdogan, 2015; Al Halbusi and Tehseen, 2017). 
In recent years, literature has broadly deliberated on the impact of ethical leadership and ethical climate in the workplace. In recent studies, Lu and Lin (2014), Demirtas and Akdogan (2015) and Aryati et al. (2018) studied the mediating role of ethical climate in the relationship between the ethical leadership and ethical behaviour of employees. However, despite studies on how the relationship between ethical leadership and ethical climate affects the ethical behaviour of employees, previous examinations have failed to take into account the condition or the boundary variables on this relationship. However, this study proposes that the personorganisation fit (P-O fit) has a vital moderating role on the relationship between the ethical climate and ethical behaviour of employees. This research has both theoretical and practical significance as it gives insights into what ethical leaders can actually do to affect the behaviour of employees. It also provides indicator of how organisations can put an emphasis on ethical climate. More importantly, it demonstrates the contingent role of P-O fit and how it contributes to the decision of employees to engage in ethical behaviour.

Furthermore, according to Van Wyk (1989) human resource management is the creation of an environment where people strive to do their best, where opportunities are equally distributed, where initiatives are encouraged and the conditions for success are created. However, management in the traditional paradigm is based on rules and regulations and the control of input and output. The new paradigm is based on shared leadership and a shared vision, honesty and transparency shaping (ethical climate) is very crucial for the employees inside the organization and for stakeholders. A deep awareness of the necessity for shared vision and transparency is the core of the new and future paradigm in education (Brown et al., 2005; Woodrow and Guest (2014). Moreover, value congruence is significant, as an implementation of the person-environment viewpoint in organisational settings (Terborg, 1981). P-O fit has usually been considered as the extent of congruence between employees and organisational norms, beliefs, values (Chatman, 1989) and goals (Kristof-Brown et al., 2005).

In essence, this study aimed to investigate the mediating role of ethical climate on the relationship between ethical leadership and the ethical behaviour of employees. Most importantly, this study examined the moderating P-O fit on the relationship between ethical climate and ethical behaviour of employees. Furthermore, no similar studies have been conducted on Middle Eastern cultures, such as the culture of Iraq. Often Iraqi organizations have a strong focus on profits, and it can be suggested they lack development in moral values, principles, and code of ethics (Al Halbusi et al., 2019a). After April 2003, the Iraqi economy collapsed due to the misconduct, mismanagement, corruption and misuse of power (Khalil, 2016). Organizations in bureaucratic state systems are perceived to be underdeveloped in many administrations, damaging Iraq's international trust in economic activities and developments. This prevailing perspective suggests that Iraqi organizations must take actions to enhance ethical standards, achieve high productivity, so as to be effective and efficient, and to increase competitive advantages in the world market. We discuss the major constructs of our theoretical model below, which may help to minimize these issues.

\section{Theory}

\subsection{Theoretical framework}

Two theories advocated by Brown and Treviño have framed our study. With respect to the understanding of ethical leadership and its consequences on the employees and the environment, Brown and Treviño (2006) have supported two theoretical frameworks, namely social learning theory (SLT) (Bandura, 1986) and social exchange theory (SET) (Blau, 1964). Social learning theory focuses on the antecedents and outcomes of ethical leadership and suggests that individuals learn the norms of appropriate conduct in two ways: through their own experience, and by observing others (Bandura, 1986). Generally, in learning such norms, individuals pay attention and consider reliable and role models (Brown and Treviño, 2006). 
Ethical leaders are considered as role models or ethical leaders when they display integrity and high standards of ethical behavior in the workplace for themselves, as well, as for others (Brown et al., 2005). Thus, employees are more probable to emulate and adopt the valuedriven behaviors of their role model ethical leader (Brown and Treviño, 2006). Role modeling impacts ethical behavior through motivational and informational means (Bandura and Walters, 1977). Leaders who are role models inspire ethical behavior by establishing the type of activities they desire to encourage and reward. Leaders, also, assist as informational leaders for appropriate behaviors.

Furthermore, researchers have suggested that followers' behaviors can be formed through the social exchange theory (Blau, 1964). Social exchange theory proposes that the norms of reciprocity or perceived obligation prompt favors that undergird many social relationships (Blau, 1964; Gouldner, 1960). Based on the social exchange theory, when individuals perceived a leader and the organization's practices (ethical climate) as caring and concerned for their well-being, they felt more committed to reciprocity with positive behavior. In line with these arguments, this study argued that ethical leaders and the organization procedures cause feelings of trust and fairness in their followers, and at an established workplace where the subordinates will probably reciprocate with positive behavior (Brown and Treviño, 2006; Brown et al., 2005). Hence, this study has used as a model for its research the social learning theory and social exchange theory.

\subsection{Ethical leadership and ethical behaviour}

As per Brown et al. (2005), ethical leadership can be described as "the demonstration of normatively appropriate conduct through personal actions and interpersonal relationships, and the advancement of such conduct to the followers through two-way communication, reinforcement, and decision making" (p. 120). Therefore, ethical leadership characterizes integrity, which involves being fair and trustworthy, having concern for others, and acting in an ethical manner (Treviño et al., 2000; Mayer et al., 2009; Ofori, 2009). Treviño et al. (2000) and Brown et al. (2005) stated that ethical leadership has two dimensions: (1) a moral personal factor, which includes integrity, fairness, concern for others and trustworthiness and (2) a moral manager factor, which includes role modelling ethical conduct, punishing, communicating and rewarding, and determining ethical standards. Mayer et al. (2009) and Lin et al. (2019) have therefore stated that the focus of a moral manager is more on transactional efforts that affect the ethical behaviour of employees.

Khuntia and Suar (2004) posit that motivating and empowering subordinates should be vital features of ethical leadership. According to Brown et al. (2005), the dimensions of ethical leadership include responding to communications, modelling behaviour, showing concern, treating employees fairly, listening to employees, and fostering trust. Furthermore, ethical leadership dimensions must also include power sharing, morality and role clarification (De Hoogh and Den Hartog, 2008).

Ethical leadership is a crucial element for ethical behaviour inside an organisation (Stead et al., 1990; Mayer et al., 2009). It has been previously indicated that leaders are a vital organisational element that has a significant effect on the ethical behaviour of employees (Stead et al., 1990; Brown et al., 2005; Treviño et al., 2014; Meyer et al., 2019; Presbitero and Teng-Calleja, 2019). Ethical managers possess positive personal attitudes and aim to influence their employees through the active management of ethical conduct. An ethical leadership displays regulated conduct in personal relationships within the organization that is directed towards strengthening and improving the ethical behaviour of employees. Socioemotional exchange is a factor where ethical leaders can influence their subordinates (Mayer et al., 2009; Lu and Lin, 2014; Dimitriou et al., 2018). A socio-emotional exchange refers to a behaviour that builds fairness and trust between employees and leaders (Blau, 1964). When employees feel that that they are being treated fairly by their leaders, they will believe that 
behaviour of their leaders is advantageous to the whole organisation. As a result, they will be less likely to act in an unethical manner (Mayer et al., 2009; Treviño et al., 2014).

It has been indicated by previous empirical studies that ethical leadership significantly influences the ethical behaviour of employees (Dickson et al., 2001; Mayer et al., 2009; Brown et al., 2005; Ofori, 2009). It has been demonstrated by more recent empirical researches that ethical leaders have a vital part in affecting the ethical behaviour of employees through their day- to- day communication with their followers (Brown et al., 2005; Ruiz-Palomino et al., 2011; Lu and Lin, 2014; Neves et al., 2018; Moore et al., 2019). The behaviour of employees may change through the standards and guidance provided by their leaders. Thus, the research hypothesis was developed based on this argument.

H1. Ethical leadership has a positive effect on the ethical behaviour of employees.

\subsection{Mediating effect of ethical climate}

According to Victor and Cullen (1988), ethical climate can be defined as the "prevailing perceptions of typical organisational practices and procedures that have ethical content" (p. 101). Also, the ethical climate of an organisation includes the normative beliefs and values about the moral issues that the employees of that organization share (Treviño et al., 1998 p. 453).

As previously stated, ethical leaders can have a strong influence on the ethical behaviour of employees. Furthermore, ethical leaders are vital components in the development of the ethical climate (Mayer et al., 2009; Brown and Treviño, 2006). Empirical evidence has indicated that ethical leaders can vitally affect and develop an ethical climate (Dickson et al., 2001; Schminke et al., 2005; Mayer et al., 2009; Kang, et al., 2011). Leaders are able to set an organisation's ethical standards through procedures, processes, and policies that help enable the employees' perceptions of the ethical climate within the organisation (Mayer et al., 2009; Demirtas et al., 2015). Schminke et al. (2005) showed consistently in their empirical research that a leader's morals combined with factors such as the regulations of the organization, orientation towards caring, orientation of the regulations, and independent judgments, are linked to the ethical climate in the organization. Therefore, it has been strongly suggested by some other studies that an ethical leadership has a vital influence on the ethical climate (Mayer et al., 2009; Engelbrecht et al., 2005; Lu and Lin, 2014). On the other hand, the ethical climate has received great attention in the literature as a factor with high potential to influence employees' ethical behavior positively (Deshpande and Joseph, 2009; Lu and Lin, 2014). An ethical climate is associated with perceptions of trust, responsibility and high moral standards regarding perceived rightness or wrongness (Luria and Yagil, 2008). Furthermore, it enforces practices, policies and procedures with strong ethical content through which it signals that "doing the right thing" is highly expected, encouraged, and valued (Treviño et al., 2014). Thus, the ethical leadership of immediate managers can shape ethical climate perceptions of direct reports, which in turn should make these employees to perceive procedures and practices that initiate and reinforce the development of ethical behavior in the workplace (Mayer et al., 2009; Lu and Lin, 2014).

As asserted above, we suggested that the ethical climate is a key mechanism on the relation of ethical leadership behaviour and the ethical behaviour of employees. Justifications have been given for the utilisation of ethical climate as a mediator in the current study. Firstly, an organisation sets its ethical standards by formulating policies, practices, and processes that assist in the facilitation of employees' perceptions of the ethical climate of the organisation. The perceptions that employees have of the ethical climate are affected by the practices and policies that the management emphasises, and the way in which the employees receive them. An ethical climate also signifies that ethical decisions are taken in terms of practices and procedures. Furthermore, it also gives consideration to "what is the right thing
Linking ethical leadership and ethical climate

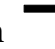


to do" in terms of ethical norms, conducts regular communication with subordinates about ethics, and rewards or punishes employees based on ethical principles. Thus, the ethical climate standards explain to employees that maintaining ethics is a vital organizational outcome (Brown et al., 2005; Mayer et al., 2009). Secondly, ethical climate is seen to be related to perceptions of responsibility, trust, and high moral standards in terms of a perceived wrongness or rightness within the organisation (Luria and Yagil, 2008; Bell et al., 2003). It has been demonstrated by previous studies that an unethical environment may lead to significant negative consequences in terms of employee behaviour within organizations (Jaramillo et al., 2005). Specifically, it is expected for the ethical climate to enforce policies, practices, and processes that aim to uphold the ethical behaviour of employees. Thirdly, it values, encourages, and expects an ethical climate with processes, measures, and policies that tell employees that they are doing the right thing. As a result, employees are more inclined to perceive an ethical organisational environment (Mayer et al., 2009). Moreover, an ethical climate that possesses clear practices, standards, and procedures shows followers how to be skilful in acknowledging ethical issues and helps them manage ethical issues. Furthermore, for subordinates receiving such signals, the ethical climate they perceive is clear and vital in the maintenance of high ethical standards without the added pressure of sacrificing ethical conduct just to achieve business objectives. In such circumstances, it is more likely for them to act with better behaviour.

It has been stated by numerous empirical researches that the leaders of an organisation influence an ethical work environment. For example, Schminke et al. (2005) investigated the relationship between the morals of the leaders and ethical climate of an organisation. Their findings reveal that the morals of a leader are related to the ethical climate of an organisation. Besides, a consistent relationship exists between ethical leaders and an ethical climate (Engelbrecht et al., 2005). Furthermore, more recent empirical studies have revealed that ethical leadership positively influences the ethical climate (Neubert et al., 2009; Lu and Lin, 2014; Demirtas et al., 2015; Choi et al., 2015). Essentially, when ethical leader's role-model appropriate behaviour, it helps them set standards for an ethical climate that values doing the right thing. Consequently, it will help employees perceive the policies and procedures of an organisation being of an ethical climate, which in turn is a motivation for them to display and act with better behaviour (Brown et al., 2005; Mayer et al., 2009; Lu and Lin, 2014). Thus, this study examined these relationships by recommending that an ethical climate is the primary mechanism between the ethical behaviour of employees and ethical leadership.

H2. An ethical climate is a mediator of the relationship between ethical leadership and the ethical behaviour of employees.

\subsection{Moderating role of person-organization fit}

Mixed findings have been obtained regarding the influences of an ethical climate on the employees' behaviour. For example, it was stated by Demirtas and Akdogan (2015) and Lu and Lin (2014) that an ethical climate positively affects the ethical behaviour of employees. Alternatively, it was demonstrated by several studies that there are inconsistent outcomes for the relationship between ethical climate and ethical behaviour among employees (Deshpande and Joseph, 2009; Duh et al., 2010; Jahantigh et al., 2016). These mixed findings indicate that ethical climate may have varying effects on the ethical behaviour of employees, based on the situation or context, such as the followers' characteristics (Yukl, 2010; Yun et al., 2006). Therefore, this study suggested that the ethical climate can have varying effects based on the followers' characteristics, particularly the person-organisation fit (P-O fit) of the followers.

Person-organization (P-O) fit has been defined in various ways as value congruence, goal congruence, the match between employees' needs and reinforcers available in the work 
environment, as well as the match between the personality of the individual and the characteristics of the organization (Chatman, 1991; McCulloch and Turban, 2007; Chatman, 1989) defined P-O fit as the congruence between the norms and values of organizations and the values of persons. This definition refers to a value-based congruence between employee and the organization. P-O fit can be defined as to how an individual's matches an organization's values, goals, and mission (Lauver and Kristof-Brown, 2001, p. 455). According to the literature, high P-O fit leads to more successful and competitive organizations and employees (Boxx et al., 1991; Chatman, 1989, 1991; Meglino et al., 1989; O’Reilly et al., 1991). There are many positive effects of high congruence between person and organization both for employees and organizations. A greater degree of P-O fit has been shown to be related to multiple organizational outcomes including enhanced organizational commitment, increased productivity, and employees' ethical behaviour (Van Vianen, 2001; Ruiz-Palomino et al., 2013). Since it is likely that the relationship between the ethical climate and ethical behaviour of employees will be generalizable across settings and non-zero (Kish-Gephart et al., 2010), the strength of the association is projected to significantly shift as a function of the way in which one measures and conceptualises the ethical climate. Apart from this, in this study the aforementioned literature about the role of different types of value congruences was raised in this study (e.g. Liedtka, 1989; Valentine et al., 2002; Elango et al., 2010; Kristof-Brown et al., 2005) to posit that the overall P-O fit significantly influences organisational outcomes.

As an implementation of the person-environment viewpoint in organisational settings (Terborg, 1981), P-O fit has usually been considered as the extent of congruence between employees and organisational norms, beliefs, values (Chatman, 1989), and goals (KristofBrown et al., 2005). The importance associated with the extent of P-O fit is consistent with various theoretical frameworks, which include the theory of cognitive dissonance (Festinger, 1957). When implemented in the work environment, this theory states that the resulting dissonance would produce negative work and organisational results when employees perceive a meaningful inconsistency between their values and norms, and those of the organisation. On the other hand, a high degree of overall P-O fit can potentially satisfy human desires, needs, and preferences (Chatman, 1989; Kristof, 1996). It can therefore produce positive subjective experiences (Vilela et al., 2008), which include positive behaviour (Verquer et al., 2003; Kristof-Brown et al., 2005; Ruiz-Palomino et al., 2013).

More importantly, the P-O fit construct can also be applied to contexts where the fit has a narrower definition to refer to perceived ethicality differences between employees and the organisations they belong to. It has been previously noted that there is no proof that different kinds of value incongruences can influence the ethical behaviour of employees (Liedtka, 1989; Elango et al., 2010). For instance, Liedtka (1989) reported that moral incongruence, which can be found either among the individual's values or among the values that are experienced within the organisation, negatively impact ethical decision- making. This agrees with the belief that perceived value differences between employees and the organisation can be seen on as a poor overall P-O fit, which translates into lower ethical behaviour. Analogously, it was discovered by Elango et al. (2010) that in the context of international business, ethical behaviour was observed to be highest in the subset of a sample both the individuals and their organizations have high scores on evaluations of ethics. Lastly, when seen from the perspective of a social learning theory (Bandura and Walters 1977), it is reasonable for one to assume that ethical climate practices and values (for example) have a good impact to the degree that the behaviours being shown coincide with the values of the employees. In general, ethical climate can have varying effects on the ethical behaviour of employees as a function of the apparent overall P-O fit. Thus, the following hypothesis was formulated with this as the basis (see Figure 1).

H3. There will be a stronger relationship between an ethical climate and the ethical behaviour of employees for employees who possess a higher perceived P-O fit. 


\section{PR}

Figure 1.

Proposed research framework

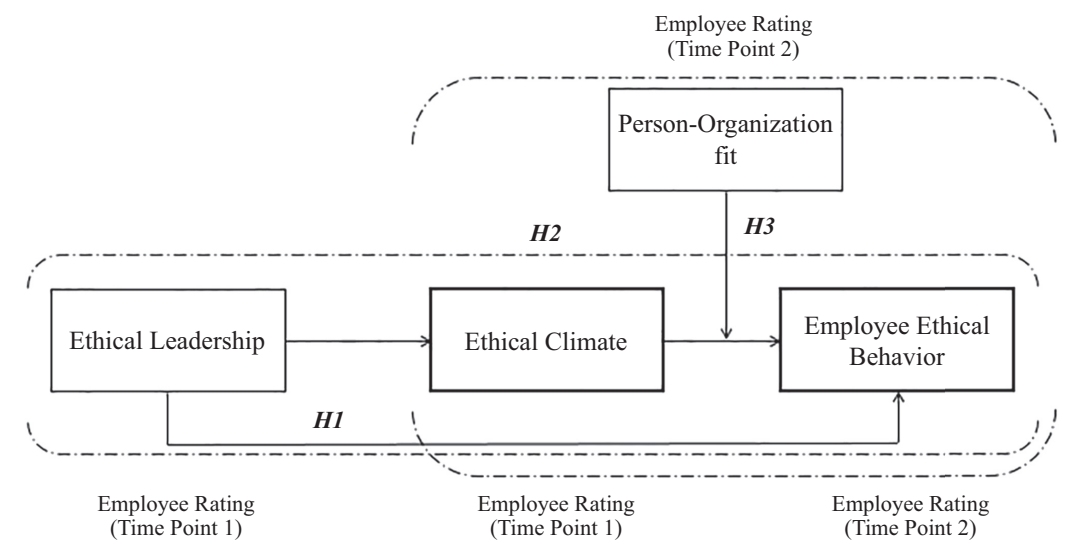

First-Order Construct

Second-Order Construct

\section{Research method}

\subsection{Sample and procedures}

To evaluate the research hypotheses, two-waves data were collected from 295 individuals who are currently employed in various Iraqi organizations (i.e., manufacturing, medical, and insurance industries). Researchers chose this approach to collect data from various organizations for several reasons. First, this approach gives an advantage due to the large number of respondents compared to one or two organizations. Second, one clear advantage is that data collected from distinct sector is more reflective of the broader population than data collected in more restricted settings (one organization) (Zehir and Erdogan, 2011). Third, this allows the researcher examining topics of a sensitive nature (e.g., ethical behavior) to receive responses less inhibited by social desirability, which may influence the results (Al Halbusi et al., 2019b).

Prior to conducting the survey, senior human resources were approached in each organization to ask permission for the study: once permission was granted, the survey was distributed. Survey packets containing the questionnaire, a prestamped envelope, and a cover letter were sent to 295 employees. The covering letter explained the purpose of the survey, assured the confidentiality of their responses, and requested that respondents return the completed survey directly using the prestamped envelope. The refusal rate was very low.

\subsection{Measurement}

All the item scales were adapted from previous studies. Since the respondents spoke Arabic, the questionnaire had to be precisely translated from English to Arabic. A backtranslation was therefore conducted. This procedure has been extensively used to test a translation's precision within a cross-cultural survey (Brislin, 1980). First, the items were translated into Arabic and then two bilingual speakers compared the translation with its original English version to assess if any discrepancies in semantic equivalence occurred. If a difference were detected, a cycle of retranslation and evaluation was repeated until no further problems were detected by the two bilingual speakers. Finally, the agreement rate 
of this process was high. Subsequently, in this study a pre-test and pilot test were performed to ensure the validity of the survey before the primary data collection stage (Memon et al., 2017).

3.2.1 Ethical leadership. Brown et al. (2005) developed the ethical leadership scale (ELS) used in this study. The scale was made up of 10 items. The following is an example of an item: "My supervisor listens to what employees have to say". Respondents will respond through a 5 -point Likert scale ranging from " 1 = Strongly Disagree" to " $5=$ Strongly Agree".

3.2.2 Ethical climate. Victor and Cullen (1988) developed the ethical climate scale used in this survey. It is made up of 14 items that were all, also, utilised in this study. The following is an example of an item: "In my organization, it is expected that you will always do what is right for the customers and public". The response is given in the form of a 5-point Likert scale that ranges from " 1 = Strongly Disagree" to " $5=$ Strongly Agree".

3.2.3 Person-organisation fit ( $P$-O fit). Measurement of the P-O fit was done with a fouritem scale. These items were taken from Cable and Judge 1996; Ruiz-Palomino et al., 2013). The following is an example of an item: "I feel my values match or fit this organization's values". The response given is through a 5-point Likert scale that ranges from " 1 = Strongly Disagree" to " 5 = Strongly Agree".

3.2.4 Employees' ethical behaviour. Ethical behaviour pertains to the employees' perceived ethical behaviour within their organisations. Measurement of this variable was done using sixteen items adapted from previous studies (Ferrell et al., 2000; Lu and Lin, 2014). Ethical behaviour has two dimensions, namely, normative ethical and juridical ethical behaviour. Since there was a relationship between the items under normative ethical behaviour and the activities, the factor was thus classified to be a normative ethical behaviour dimension. On the other hand, the juridical ethical behaviour dimension was made up of six items. Because these items can be considered professional ethical-related activities, the factor was thus classified as a juridical ethical behaviour dimension. Examples of an item include "I use company services appropriately and not for personal use". The response is in the form of a 5-point Likert scale ranging from " 1 = Strongly Disagree" to "5 = Strongly Agree".

\section{Minimization of common method variance}

Common method variance (CMV) is a vital concern of any research, particularly if data is obtained from a common source or self-reported as in this study. Podsakoff et al. (2003, 2012) suggested some remedies that were used in this study for the minimisation of common method bias. For example, the collection of the independent and dependent variables was conducted at various times. To lessen the influence of common method variance (CMV) two surveys were administered 3 weeks apart. This survey also introduced a time lag to lessen consistency motifs. In the first wave, subordinates provided their demographic information, assessed their immediate supervisors' ethical leadership behaviours and rated their perception of the ethical climate as well. Subsequently, three weeks later in the second wave, the employees rated their PO fit and ethical behaviour. The respondents were also provided with descriptions for every construct, with precise directions on completing the assessment of the items in order to prevent any confusion. The respondents were given assurance of the study's academic nature as well as of the confidentiality of their identities. They were also reminded that there were no incorrect or correct answers in order to reduce evaluation apprehension. Both sets of surveys were coded to confirm that the responses could be matched later. 350 questionnaires were distributed in both waves. Out of these 350 surveys, only 295 were valid as a final set a total of $84 \%$ representing the response rate. Finally, only 295 matched subordinate responses were obtained across two-waves.
Linking ethical leadership and ethical climate

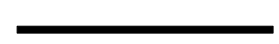


This study utilised structural equation modelling via the partial least squares (PLS) method. The research model was then analysed using the SmartPLS 3.2.6 software (Ringle et al., 2015). This study utilised the two-stage analytical technique that Anderson and Gerbing (1988) and Hair et al. (2017) recommended. It begins with the measurement model assessment (constructs reliability and validity) and is followed by the structural model assessment (tests the hypothesised relationships).

\subsection{Demographic profile of respondents}

This section includes the respondents' demographic information, which was gathered using SPSS version 23 . As revealed, $75.9 \%$ of the respondents were males, and $24.1 \%$ were females. In terms of age, the majority of the employees (43.4\%) ranged from 31 to 40 years. With regard to their educational background, the highest percentage of $56.6 \%$ represented people who were bachelor's degree holders. In terms of job experience, $38.0 \%$ of the employees had been working for between 6-10 years. In terms of the type of organization, the highest score of $17.6 \%$ went to the insurance industry. The details are presented in Table 1.

\subsection{Measurement model assessment}

The measurement model was evaluated through construct validity (including discriminant and convergent validities) and construct reliability. In terms of construct reliability, the individual Cronbach's alpha values were tested to evaluate the reliability of core variables in the measurement model. Results indicated that all the individual Cronbach's alpha values, which ranged from (0.709-0.920), were more than the suggested 0.7 value (Nunnally and Bernstein, 1994; Hair et al., 2017). Additionally, the composite reliability (CR) was used by this study to test the construct reliability, which also gave the suggested value. Therefore, the values obtained, which ranged from (0.869-0.930), were seen to be more than 0.7 (Hair et al., 2017). This is an adequate signifier that the construct reliability was achieved, as demonstrated in Table 2. Therefore, the CR and Cronbach's alpha obtained for all the

\begin{tabular}{llcc}
\hline Demographic item & Categories & Frequency & Percentage \\
\hline \multirow{2}{*}{ Gender } & Male & 224 & 75.9 \\
& Female & 71 & 24.1 \\
& Less than 25 Years & 17 & 5.8 \\
& 25-30 Years & 66 & 22.4 \\
& 31-40 Years & 128 & 43.4 \\
& 41-50 Years & 60 & 20.3 \\
Level of education & More than 51 Years & 24 & 8.1 \\
& High School & 46 & 14.9 \\
& Diploma & 47 & 15.9 \\
& Bachelor's Degree & 167 & 56.6 \\
Job experience & Master's Degree & 19 & 6.1 \\
& Doctorate Degree & 16 & 4.4 \\
& 2 Years or Less & 17 & 5.8 \\
& 3-5 Years & 60 & 20.3 \\
Organization type & 6-10 Years & 112 & 38.0 \\
& 11-15 Years & 31 & 10.5 \\
& 16 Years or More & 75 & 25.4 \\
& Manufacturing & 99 & 25.4 \\
& Medical organizations & 103 & 38.0 \\
& Insurance & 93 & 23.6 \\
\hline
\end{tabular}

Table 1.

Profile of respondents 


\begin{tabular}{|c|c|c|c|c|c|c|c|c|}
\hline $\begin{array}{l}\text { First-order } \\
\text { constructs }\end{array}$ & $\begin{array}{l}\text { Second- } \\
\text { order } \\
\text { constructs }\end{array}$ & Items & Items descriptions & $\begin{array}{l}\text { Loading } \\
(>0.5)\end{array}$ & $\begin{array}{c}\mathrm{CA} \\
(>0.7)\end{array}$ & $\begin{array}{c}\mathrm{CR} \\
(>0.7)\end{array}$ & $\begin{array}{l}\text { AVE } \\
(>0.5)\end{array}$ & $\begin{array}{l}\text { Linking ethical } \\
\text { leadership and } \\
\text { ethical climate }\end{array}$ \\
\hline \multirow[t]{10}{*}{$\begin{array}{l}\text { Ethical } \\
\text { Leadership }\end{array}$} & & EL1 & $\begin{array}{l}\text { My supervisor listens to } \\
\text { what employees have to say }\end{array}$ & 0.636 & \multirow[t]{10}{*}{0.911} & \multirow[t]{10}{*}{0.926} & \multirow[t]{10}{*}{0.558} & \\
\hline & & EL2 & $\begin{array}{l}\text { My supervisor disciplines } \\
\text { employees who violate } \\
\text { ethical standards }\end{array}$ & 0.640 & & & & \\
\hline & & EL3 & $\begin{array}{l}\text { My supervisor conducts his/ } \\
\text { her work in an ethical } \\
\text { manner }\end{array}$ & 0.754 & & & & \\
\hline & & EL4 & $\begin{array}{l}\text { My supervisor has the best } \\
\text { interests of employees in } \\
\text { mind }\end{array}$ & 0.810 & & & & \\
\hline & & EL5 & $\begin{array}{l}\text { My supervisor makes fair } \\
\text { decisions }\end{array}$ & 0.735 & & & & \\
\hline & & EL6 & $\begin{array}{l}\text { My supervisor can be } \\
\text { trusted }\end{array}$ & 0.734 & & & & \\
\hline & & EL7 & $\begin{array}{l}\text { My supervisor discusses } \\
\text { business ethics or values } \\
\text { with employees }\end{array}$ & 0.752 & & & & \\
\hline & & EL8 & $\begin{array}{l}\text { My supervisor sets an } \\
\text { example of how to do things } \\
\text { the right way in terms of } \\
\text { ethics }\end{array}$ & 0.811 & & & & \\
\hline & & EL9 & $\begin{array}{l}\text { My supervisor defines } \\
\text { success not just by results } \\
\text { but also the way that they } \\
\text { are obtained }\end{array}$ & 0.782 & & & & \\
\hline & & EL10 & $\begin{array}{l}\text { When making decisions, my } \\
\text { supervisor asks, "what is the } \\
\text { right thing to do?" }\end{array}$ & 0.795 & & & & \\
\hline \multirow[t]{3}{*}{ Caring } & & $\mathrm{EC} 1$ & $\begin{array}{l}\text { What is best for everyone in } \\
\text { my organization is the major } \\
\text { consideration here }\end{array}$ & 0.861 & \multirow[t]{3}{*}{0.809} & \multirow[t]{3}{*}{0.887} & \multirow[t]{3}{*}{0.724} & \\
\hline & & $\mathrm{EC} 2$ & $\begin{array}{l}\text { In my organization, it is } \\
\text { expected that you will } \\
\text { always do what is right for } \\
\text { the customers and public }\end{array}$ & 0.851 & & & & \\
\hline & & EC3 & $\begin{array}{l}\text { In my organization, each } \\
\text { person is expected above all } \\
\text { to work efficiency }\end{array}$ & 0.840 & & & & \\
\hline \multirow[t]{4}{*}{ Independence } & & $\mathrm{EC4}$ & $\begin{array}{l}\text { In my organization, } \\
\text { employees are expected to } \\
\text { follow their own personal } \\
\text { and moral beliefs }\end{array}$ & 0.910 & \multirow[t]{4}{*}{0.709} & \multirow[t]{4}{*}{0.871} & \multirow[t]{3}{*}{0.772} & \\
\hline & & EC5 & $\begin{array}{l}\text { In my organization, } \\
\text { employees are guided by } \\
\text { their own personal ethics }\end{array}$ & 0.846 & & & & \\
\hline & & EC6 & $\begin{array}{l}\text { In my organization, } \\
\text { employees are expected to } \\
\text { follow their own personal } \\
\text { and moral beliefs }\end{array}$ & Dropped & & & & $\begin{array}{r}\text { Table 2. } \\
\text { Measurement model, } \\
\text { item loadings, } \\
\text { construct reliability } \\
\text { and convergent }\end{array}$ \\
\hline & & & & & & & inued) & validity \\
\hline
\end{tabular}


PR

\begin{tabular}{|c|c|c|c|c|c|c|c|}
\hline $\begin{array}{l}\text { First-order } \\
\text { constructs }\end{array}$ & $\begin{array}{l}\text { Second- } \\
\text { order } \\
\text { constructs }\end{array}$ & Items & Items descriptions & $\begin{array}{l}\text { Loading } \\
(>0.5)\end{array}$ & $\begin{array}{c}\mathrm{CA} \\
(>0.7)\end{array}$ & $\begin{array}{c}\mathrm{CR} \\
(>0.7)\end{array}$ & $\begin{array}{l}\text { AVE } \\
(>0.5)\end{array}$ \\
\hline \multirow[t]{3}{*}{ Law and Code } & & $\mathrm{EC} 7$ & $\begin{array}{l}\text { In my organization, the law } \\
\text { or ethical code of their } \\
\text { profession is the major } \\
\text { consideration }\end{array}$ & 0.822 & 0.774 & 0.869 & 0.689 \\
\hline & & EC8 & $\begin{array}{l}\text { Employees are expected to } \\
\text { comply with the law and } \\
\text { professional standards over } \\
\text { and above other } \\
\text { considerations }\end{array}$ & 0.863 & & & \\
\hline & & EC9 & $\begin{array}{l}\text { In my organization, } \\
\text { employees are expected to } \\
\text { strictly follow legal or } \\
\text { professional standards }\end{array}$ & 0.804 & & & \\
\hline \multirow[t]{2}{*}{ Rules } & & $\mathrm{EC} 10$ & $\begin{array}{l}\text { It is very important to follow } \\
\text { the organization's rules and } \\
\text { procedures }\end{array}$ & 0.828 & 0.771 & 0.857 & 0.749 \\
\hline & & EC11 & $\begin{array}{l}\text { Everyone is expected to } \\
\text { stick by organization's rules } \\
\text { and procedures }\end{array}$ & 0.902 & & & \\
\hline \multirow[t]{8}{*}{ Instrumental } & & $\mathrm{EC} 12$ & $\begin{array}{l}\text { Employees are expected to } \\
\text { do anything to further the } \\
\text { organization's interests, } \\
\text { regardless of the } \\
\text { consequences }\end{array}$ & 0.856 & 0.805 & 0.885 & 0.719 \\
\hline & & $\mathrm{EC} 13$ & $\begin{array}{l}\text { In my organization, people } \\
\text { protect their own interests } \\
\text { above all else }\end{array}$ & 0.852 & & & \\
\hline & & EC14 & $\begin{array}{l}\text { Employees are expected to } \\
\text { do anything to further the } \\
\text { organization's interests, } \\
\text { regardless of the } \\
\text { consequences }\end{array}$ & 0.835 & & & \\
\hline & $\begin{array}{l}\text { Ethical } \\
\text { Climate }\end{array}$ & Caring & & 0.881 & 0.872 & 0.897 & 0.881 \\
\hline & & Independence & & 0.711 & & & \\
\hline & & Law and Code & & 0.870 & & & \\
\hline & & Rules & & 0.757 & & & \\
\hline & & Instrumental & & 0.633 & & & \\
\hline \multirow{4}{*}{$\begin{array}{l}\text { Person } \\
\text { organization } \\
\text { fit }\end{array}$} & & P-O Fit1 & $\begin{array}{l}\text { I feel my values match or fit } \\
\text { this organization's values }\end{array}$ & 0.883 & 0.826 & 0.883 & 0.749 \\
\hline & & P-O Fit2 & $\begin{array}{l}\text { My organization's objective } \\
\text { reflects your own objectives }\end{array}$ & 0.749 & & & \\
\hline & & P-O Fit1 3 & $\begin{array}{l}\text { The personality of this } \\
\text { organization reflects your } \\
\text { own personality }\end{array}$ & 0.558 & & & \\
\hline & & P-O Fit1 4 & $\begin{array}{l}\text { My organization's values } \\
\text { and culture provide a good } \\
\text { fit with the things that you } \\
\text { value in life }\end{array}$ & Dropped & & & \\
\hline
\end{tabular}

(continued)

Table 2. 


\begin{tabular}{|c|c|c|c|c|c|c|c|c|}
\hline $\begin{array}{l}\text { First-order } \\
\text { constructs }\end{array}$ & $\begin{array}{l}\text { Second- } \\
\text { order } \\
\text { constructs }\end{array}$ & Items & Items descriptions & $\begin{array}{c}\text { Loading } \\
(>0.5)\end{array}$ & $\begin{array}{c}\mathrm{CA} \\
(>0.7)\end{array}$ & $\begin{array}{l}\mathrm{CR} \\
(>0.7)\end{array}$ & $\begin{array}{l}\text { AVE } \\
(>0.5)\end{array}$ & $\begin{array}{l}\text { Linking ethical } \\
\text { leadership and } \\
\text { ethical climate }\end{array}$ \\
\hline \multirow{10}{*}{$\begin{array}{l}\text { Normative } \\
\text { ethical } \\
\text { behavior }\end{array}$} & & EEB1 & $\begin{array}{l}\text { I take responsibility for my } \\
\text { own errors }\end{array}$ & 0.700 & 0.880 & 0.904 & 0.513 & \\
\hline & & EEB2 & $\begin{array}{l}\text { I give credit to those who } \\
\text { deserve it }\end{array}$ & 0.596 & & & & \\
\hline & & EEB3 & $\begin{array}{l}\text { I use company services } \\
\text { appropriately and not for } \\
\text { personal use }\end{array}$ & 0.738 & & & & \\
\hline & & EEB4 & I am open about my errors & 0.773 & & & & \\
\hline & & EEB5 & $\begin{array}{l}\text { I conduct only company } \\
\text { business on company time }\end{array}$ & 0.705 & & & & \\
\hline & & EEB6 & $\begin{array}{l}\text { I do not give gifts/favors in } \\
\text { exchange for preferential } \\
\text { treatment }\end{array}$ & 0.740 & & & & \\
\hline & & EEB7 & $\begin{array}{l}\text { I keep confidential } \\
\text { information confidential }\end{array}$ & 0.771 & & & & \\
\hline & & EEB8 & $\begin{array}{l}\text { I take the appropriate } \\
\text { amount of time to do a job }\end{array}$ & 0.664 & & & & \\
\hline & & EEB9 & $\begin{array}{l}\text { I report others' violation of } \\
\text { company policies and rules }\end{array}$ & Dropped & & & & \\
\hline & & EEB10 & $\begin{array}{l}\text { I lead my subordinates to } \\
\text { behave ethically }\end{array}$ & 0.740 & & & & \\
\hline \multirow{8}{*}{$\begin{array}{l}\text { Juridical } \\
\text { ethical } \\
\text { behavior }\end{array}$} & & EEB11 & $\begin{array}{l}\text { I am careful with company } \\
\text { materials and supplies }\end{array}$ & 0.776 & 0.849 & 0.889 & 0.576 & \\
\hline & & EEB12 & $\begin{array}{l}\text { I request reimbursement } \\
\text { only for allowed expenses }\end{array}$ & 0.770 & & & & \\
\hline & & EEB13 & $\begin{array}{l}\text { I come to work unless I am } \\
\text { sick }\end{array}$ & 0.570 & & & & \\
\hline & & EEB14 & $\begin{array}{l}\text { I refuse gifts that are offered } \\
\text { for preferential treatment }\end{array}$ & 0.748 & & & & \\
\hline & & EEB15 & $\begin{array}{l}\text { I take only the allotted/ } \\
\text { assigned personal time } \\
\text { (lunch hour, breaks) }\end{array}$ & 0.853 & & & & \\
\hline & & EEB16 & $\begin{array}{l}\text { I complete time/quality/ } \\
\text { quantity reports honestly }\end{array}$ & 0.806 & & & & \\
\hline & $\begin{array}{l}\text { Employees' } \\
\text { ethical } \\
\text { behavior }\end{array}$ & $\begin{array}{l}\text { Normative } \\
\text { Ethical } \\
\text { Behavior }\end{array}$ & & 0.955 & 0.920 & 0.930 & 0.872 & \\
\hline & & $\begin{array}{l}\text { Juridical } \\
\text { Ethical } \\
\text { Behavior }\end{array}$ & & 0.912 & & & & \\
\hline \multicolumn{8}{|c|}{$\begin{array}{l}\text { Note(s): CA = Cronbach's Alpha, } \mathrm{CR}=\text { Composite Reliability, AVE }=\text { Average Variance Extracted; EEB9, } \\
\text { EC6, and P-O Fit4 were dropped due to the low loading }\end{array}$} & Table 2. \\
\hline
\end{tabular}

constructs can be classified as sufficiently error-free. To test the reliability indicator, factor loading was utilised. High loadings on a construct are indicators that the associated indicators would seem to have a lot in common, in such a way that the construct was able to capture them (Hair et al., 2017). For factor loadings, values higher than 0.50 were classified as very significant (Hair et al., 2010, 2017). As seen in Table 2, the loadings for all the items were more than the suggested value of 0.5, except for items EEB9, EC6 and P-O Fit4. These items were removed from the scale because of low loadings. For the remaining items in the model, the loading met all the requirements (see Table 2). 
For testing the convergent validity (the degree to which a measure is positively correlated to alternative measures of the same construct), the average variance extracted (AVE) was used in this study. This is an indication that all the values of AVE ranging from (0.558-0.881) were higher compared to the recommended value of 0.50 (Hair et al., 2017). For all constructs, the convergent validity was met successfully, and an adequate convergent validity was achieved, as presented in Table 2.

This study assessed the discriminant validity (the extent of differentiation of items among constructs or the measure of individual concepts) using the heterotrait-monotrait (HTMT) ratio criteria. This criterion was selected instead of the Fornell-Larcker criterion because there have been some criticisms with regard to the latter. According to Henseler et al. (2015), the Fornell-Larcker criterion fails to accurately reveal the absence of discriminant validity during common research situations. The heterotrait-monotrait (HTMT) ratio of correlations was proposed as an alternative technique based on the multitrait-multimethod matrix. Thus, the discriminant validity was evaluated by this study through the HTMT ratio of correlations. However, the discriminant validity encounters an issue when the HTMT value is more than the $\mathrm{HTMT}_{0.85}$ value of 0.85 (Kline, 2010). As shown in Table 3 , all the values were less than the recommended value. This signifies that the validity of the discriminant had been determined.

Table 3.

Discriminant validity via (HTMT criterion)

\begin{tabular}{lcccr}
\hline Constructs & EB & EC & EL & POF \\
\hline EB & & & \\
EC & 0.768 & 0.647 & \\
EL & 0.632 & 0.454 & 0.433 \\
POF & 0.454 & 0.592 & \\
Note(s): Key: EB $=$ Ethical Behaviour, EC $=$ Ethical Climate, EL = Ethical Leadership, POF = Person- \\
Organization Fit
\end{tabular}

\subsection{Structural model assessment}

Hair et al. (2017) have recommended a particular criterion while evaluating the structural model. This criterion involves examining the initial stage to the collinearity issue. The $R^{2}$, beta $(\beta)$, and the corresponding t-values then follow through a bootstrapping procedure, including a re-sample of 5,000. It was also recommended to report the predictive relevance $\left(Q^{2}\right)$ and the effect sizes $\left(f^{2}\right)$ as well. Sullivan and Feinn (2012) have posited that while the $p$ value determines the existence of the effect, it does not reveal how big the effect is.

\subsection{Hypothesis testing}

The hypothesis testing provided the first indication of the direct effect, namely, that ethical leadership significantly predicts ethical behaviour. Hence, $\mathrm{H} 1$ was accepted with $(\beta=0.229$, $t=4.083$, and $p<0.000$ ). The results are shown in Table 4.

For the mediation hypothesis (indirect effect), it was suggested by Hair et al. (2017) that researchers should follow the technique of Preacher and Hayes (2004) and Preacher and Hayes (2008) during the testing of the mediating effects. In this study, the test of the indirect effect (mediation effect) of ethical climate had its basis in the method developed by Preacher and Hayes (2004) and Preacher and Hayes (2008), which involves bootstrapping the indirect effect. Table 5 presents the results obtained from the bootstrapping analysis.

The findings revealed that there was a significant indirect effect, with $(\beta=0.275$, $t=8.898$, and $p<0.000$ ). However, it was mentioned by Preacher and Hayes (2008) that when the $0.275,95 \%$ Boot CI: $[\mathrm{LL}=0.224$, UL $=0.352]$ and a 0 is not straddled in between, mediation exists. Thus, one can conclude in this study that the mediation effect of the ethical 


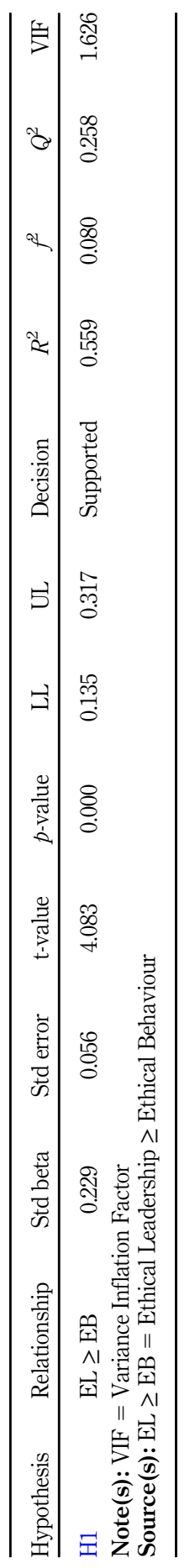

Linking ethical leadership and ethical climate 
climate had statistical significance between ethical behaviour and ethical leadership. Hence, the mentioned results also supported $\mathrm{H} 2$, as observed in Table 5.

In accordance with the goals of this study, the moderation test was the key contribution for determining if the P-O fit moderates the relationship between ethical climate and employees' ethical behaviour. According to Hair et al. (2017, p. 271), "Moderation occurs when the strength or even the direction of a relationship between two constructs depends on a third variable". Hence, the nature of the relationship varies as per the third variable's value. Furthermore, the moderator is considered an independent latent variable that affects the direction or strength of the relationship between the dependent variable and predictor variable (Baron and Kenny, 1986, p. 1174). Therefore, given the objective of this study, testing was done on the moderation effect of the "P-O fit" and the relationship between the ethical climate and ethical behaviour of employees. As stated earlier, the PLS bootstrapping method with 5,000 re-samples was performed on the structural model to generate the t-values. Thus, the results of the moderation analysis $(\beta=0.160, t=2.490, p<0.007)$, as presented in Table 6 , showed that H3 was supported.

Generally, it is not quite clear as to how a moderation analysis differs between a high and low interaction. In other words, the size of the precise nature of this effect is not easy to define from the analysis of the coefficient itself (Dawson, 2014). Thus, Dawson (2014) suggested that this be followed up by an interaction plot. Hence, this study employed an interaction plot. Based on the results and the interpretation of the plot, Figure 2 demonstrates the relationship among the ethical climate, employees' ethical behaviour, and the P-O fit. For the interaction effect, the resultant graph illustrates that ethical climate and employees' ethical behaviour had a stronger positive relationship (the slope was more pronounced) when employees had a higher P-O fit, which supports H3 (Figure 2). Therefore, ethical climate and employees' ethical behaviour had a stronger relationship when the employees possess a higher P-O fit more than lower.

As stated earlier in the analysis section, the issue of collinearity is crucial with regard to a structural model. Hair et al. (2017) state that there is a multi-collinearity issue when the largest VIF has a value greater than 5 . However, multicollinearity diagnostic is noted in Table 4 and Table 6 through the VIF, which is an indication that no evidence of significant multicollinearity exists among the exogenous constructs in the study since all the VIF values were less than 5 ranged from 1.403 to 1.626). This signifies that the variations observed in the exogenous constructs, and expounded on in the endogenous construct, did not overlap.

In general, the values of $R^{2}$ obtained an acceptable degree of explanatory power, as suggested by Cohen (1988) and Chin (1998a, b). This accounts for the $0.617 \%$ variance in the given research model which can be classified as a moderate-to substantial effect (Hair et al., 2017). Also, the Stone-Geisser blindfolding sample reuse technique reveals $Q^{2}$ is another criterion that has to be assessed during a structural model analysis. This study investigated the power of the proposed research model in terms of predictive relevance and through the utilisation of the blindfolding procedure. Hair et al. (2017) recommended using the blindfolding procedure only on endogenous constructs. If $Q^{2}$ has a value greater than 0 , then there is a predictive relevance of the proposed model for a particular endogenous construct (Fornell and Cha, 1994; Hair et al., 2017). Table 4 shows that the $Q^{2}$ value was 0.258

Table 5.

Mediating test (Indirect effect)

\begin{tabular}{lcccccccc}
\hline Hypothesis & Relationship & Std beta & Std error & $t$-value & $p$-value & LL & UL & Decision \\
\hline H2 & EL $\geq \mathrm{EC} \geq \mathrm{EB}$ & 0.275 & 0.031 & 8.898 & 0.000 & 0.224 & 0.352 & Supported \\
Source(s): $\mathrm{EL} \geq \mathrm{EC} \geq \mathrm{EB}=$ & Ethical Leadership $\geq$ Ethical Climate $\geq$ Ethical Behaviour & & \\
\hline
\end{tabular}




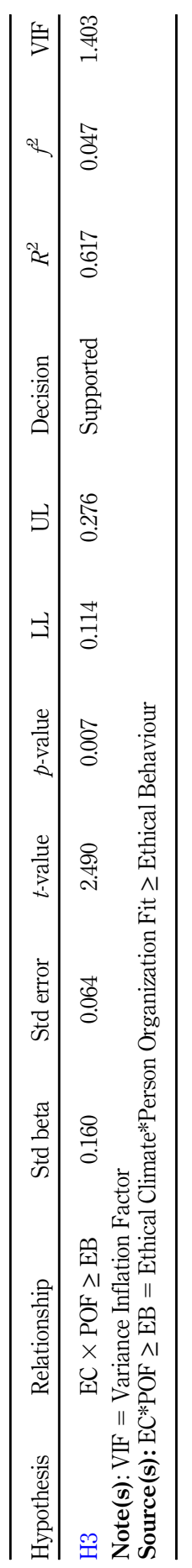

Linking ethical leadership and ethical climate 


\section{PR}

\section{Figure 2.}

Interacting effects of $\mathrm{P}$ -

O fit with ethical

climate on the ethical

behaviour of employees

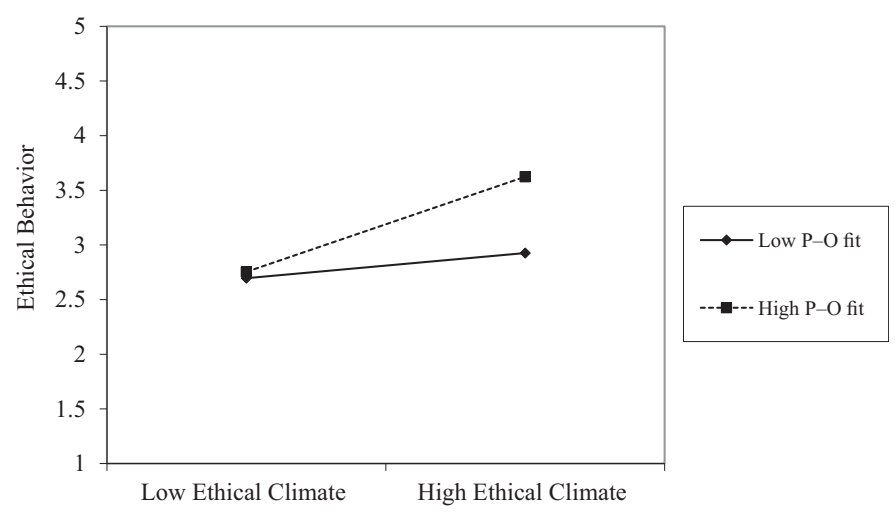

(greater than 0), which signified that the proposed model had an adequate predictive relevance. Hair et al. (2017) suggested $Q^{2}$ values of 0.35 (large), 0.15 (medium) and 0.02 (small) to be used as relative measures of predictive relevance. Hence, this study revealed that the endogenous construct exhibited a large predictive relevance.

In term of the effect size $\left(f^{2}\right)$, which can be used in determining whether an exogenous latent construct has a weak, moderate, or substantial effect on an endogenous latent construct (Gefen and Rigdon, 2011), it was recommended by Hair et al. (2017) that a test should be conducted on the change in the $R^{2}$ value. Cohen (1988) suggested a magnitude of $f^{2}$ at 0.02 (small effects), 0.15 (medium effects), and 0.35 (large effects), as guideline measures. Thus, as indicated in Table 4 and Table 6 , the $f^{2}$ presented large effect sizes.

\section{Discussion and implications}

Ethics refer to the norms, standards, and values that direct the behaviour of an individual (Treviño et al., 2014; Bright et al., 2014). Ethical behaviour is vital in society because human beings need to be treated with respect. As previously stated, the focus of earlier studies were focused on the antecedents of the employees' ethical behaviour to determine the factors that would enhance ethical behaviour within an organisation and improve the relationship between leaders and their subordinates (Brown et al., 2005; Mayer et al., 2009). Thus, this study examined how the ethical behaviour of leaders is related to the ethical behaviour of employees by using an ethical climate as the mediator. Most importantly, the current study determined that the person-organization fit is an important moderator of the relationship between ethical climate and employees' ethical behaviour.

\subsection{Theoretical implications}

This study Contributes to the literature on ethical leadership and ethical behaviour of employees in terms of the following aspects. Firstly, earlier studies in general, have observed that perceived ethical leadership has a positive effect on the employees' ethical behaviours (e.g. Mayer et al., 2009; Lu and Lin, 2014). However, these studies were not able to identify the underlying mechanism that connected perceived ethical leadership to the employees' ethical behaviours (Treviño et al., 2014). Hence, this study was able to determine the relationship between ethical leadership and employees' ethical behaviours via the ethical climate as one of the significant underlying mechanisms. Consequently, this study contributes to this limited stream of research with findings that support and help generalize this relationship in another country and context, which encompasses different ethnicities. Iraq is considered a 
multicultural country which encompasses Arab (Suni and Shina), Kurds, Yazidis and other ethnicities with important differences in terms of beliefs, religion, ideology, and identity (Al Halbusi et al., 2019a), thus this study is a an asset for the generalization of this relationship across different culture.

Secondly, this study was able to determine that the P-O fit is a vital boundary condition for identifying the effect of ethical climate on the employees' ethical behaviours. Even though past researches have determined the link between the ethical climate and ethical behaviour of employees, there are still several important questions that need to be addressed (Ruiz-Palomino et al., 2013; Decoster et al., 2019). Thus, this study includes the P-O fit being a vital moderator that reinforces ethical behaviour of employees. Therefore, this study determined that ethical climate has a stronger effect on the ethical behaviour of employees when the P-O fit is high. In other words, a high P-O fit better strengthens the relationship between the ethical climate and ethical behaviour of employees. As expected, there was a substantial change in the strength of the association as a function of the way in which the organisation and the P-O fit congruence were linked. Moreover, the study utilised the logic of the role that different types of value congruences play in order to posit that the overall Person-Organization fit significantly influences organisational outcomes. Therefore, this study also helps to confirm previous suggestions of P-O fit as a concept that influences the relationship of contextual influences on the ethical behaviour of individuals (Ruiz-Palomino et al., 2013).

\subsection{Practical implications}

In terms of management, the findings send a clear signal to those in the upper level that, without ignoring the issue of ethics in organizations, employees are a critical aspect to be taken into account to encourage ethical behaviour at the workplace. This study has important practical implications. First, managers are considered as vital sources of ethical behaviour which contributes to organisational success. This study revealed that ethical leadership has a meaningful effect on the ethical behaviour of employees. This study argued that as role models in their organizations who can engender relational attachments and model ethical leadership behaviour, managers possess a moral authority that virtuously affects the behaviour of the organisation's members. Furthermore, several important aspects Can be drawn from the results of this study. First, ethical leadership is a key factor that affects the employees' ethical behaviour. Thus, this should be taken into consideration by Iraqi organisations. Iraqi businesses should therefore try to choose or train ethical leaders, given how ethical leadership can improve the ethical behaviour of employees. Options that organisations may consider can include hiring more ethical leaders and offering existing leaders with more training. Examples of training topics include supporting and rewarding employees who behave ethically, communicating the importance of ethics, and leaders acting as role models of ethical behaviour (Demirtas, 2015; $\mathrm{Lu}$ and Lin, 2014).

Secondly, as noted earlier, the statistical results signified that ethical climate plays an important mediating role in the relationship between ethical leadership and employees' ethical behaviour. According to Victor and Cullen (1988), an ethical work climate can be defined as the "predominant perceptions about the procedures and practices of the organization that have ethical content or the prevailing perceptions of typical organizational practices and procedures that have ethical content" (p. 101). The generation of ethical behaviour depends on multifactorial entities. Manager behaviour is one of the most influential and important factors in fostering the ethical behaviour of employees. Therefore, it has been also demonstrated by the results that creating an ethical climate within the workplace is vital since an ethical climate has a positive relationship with the employees' 
ethical behaviour. To enhance ethical conduct, organisations must have leaders who inspire and exemplify ethical behaviour. Organizations should also implement systems that discipline unethical conduct and reward ethical behaviour. It is suggested by this study that Iraqi organizations must focus on the development of an ethical climate that puts emphasis on the employees' ethical behaviour by focusing on observing the law and professional standards, and also emphasising public interest instead of self-interest (Treviño et al., 1998). Therefore, the vital indication given by the results of this study is that managers who possess and exhibit ethical leadership qualities such as fairness and integrity; emphasise ethical standards; support and reward employees who behave ethically; and become role models of ethical behaviour are more capable of creating an ethical climate that values doing the right thing. When employees operate in an ethical climate, they are more likely to engage in ethical behaviour (Mayer et al., 2009; Treviño et al., 2014). Thus, this study revealed that within the Iraqi context, leaders are able to improve ethical behaviour among employees by enhancing the ethical climate. This can be done by enacting ethical rules and standards, demonstrating the highest ethical behaviour inside the organisation, and establishing very clear ethical standards. Fundamentally, an ethical climate is an important key facilitator of the relationship between the ethical behaviour of employees and ethical leadership which needs to be highly considered by the organizations.

Third, as previously mentioned, this study determined that ethical climate has a stronger effect on the ethical behaviour of employees when the P-O fit is high rather than low. The effect that ethical climate has on the employees' ethical behaviour is dependent on the P-O fit. In other words, a high P-O fit better strengthens the relationship between the ethical climate and ethical behaviour of employees. Therefore, there was a significant change in the strength of the association as a function of the way in which the organisation and the P-O fit congruence are linked. Furthermore, the study utilised the reasoning of the role that different types of value congruences play in order to posit that the overall PersonOrganization fit significantly influences organisational outcomes. Consequently, as an exemplification of the person-environment standpoint within organisational situations, the $\mathrm{P}-\mathrm{O}$ fit has normally been described as the extent of congruence between employees and organisational norms, beliefs, values (Chatman, 1989), and goals (Kristof-Brown et al., 2005). A high degree of overall P-O fit can potentially meet human needs, preferences, and desires (Chatman, 1989; Kristof, 1996). As a result, these produce positive subjective experiences (Vilela et al., 2008), such as positive behaviour (Verquer et al., 2003; KristofBrown et al., 2005). Therefore, there is a need for Iraqi organisations to highly consider the congruence of value between employees and organisational values, norms, and goals in order to obtain a strategic, sustainable and positive behaviour on their employees' parts. Thus, it was also suggested by this study that the ethical climate and the P-O fit may, to some degree, substitute for each other as they influence the ethical behaviour of employees. Therefore, firms that were identified to have a low level of ethical standards, practices, and policies, at least from the employees' perspective, are better poised to conduct ethical issues in order to construct the ethical behaviour of their subordinates. More importantly, it is highly essential that the value congruence between an organization and its followers be considered.

\section{Limitations and future studies}

The primary limitation of this study is in the data, which was obtained from a single source. Although the study conducted two surveys and utilised a mediation and moderation variables model that was less likely to be influenced by common method bias (CMB) (Podsakoff et al., 2012), one cannot completely rule out CMB. Apart from the potential effects of the $\mathrm{CMB}$, the consistency of the empirical findings could have also been compromised since 
self-reported data were utilised in measuring ethical behaviour, which can be a very complex and sensitive issue. For this reason, the social desirability response bias cannot be ruled out completely. When possible, future studies must gather data from multiple sources. Furthermore, supervisors must evaluate the ethical behaviour of employees.

Another limitation was that the findings of this study were based on a sample in a Middle Eastern cultural context such as in Iraq. Perhaps, the particular cultural features of this context, which encompassed, among other things, a strong adherence to religious values (Moaddel, 2010), could have influenced the findings of this study. It is true that the effects of differences (P-O fit) are highly likely to replicate across cultural contexts (Triandis et al., 1988). However, it can be seen that further studies are needed to evaluate the context-sensitivity of these findings (Whetten, 2009) by analysing other cultures, where the importance of religiosity is on the decline (i.e., in Western countries, Ribberink et al., 2018) or where the cultural features are very much different from those that apply to Iraq.

Lastly, other external factors were not taken into account by this study as it tried to explain ethical behaviour. Ethics is a highly complex subject and is influenced by numerous variables at the organisational, individual and external environment levels. Thus, caution must be observed when making inferences from the present study which, to a certain degree, offered a simplified version of ethical behaviour by concentrating on a few variables such as the Arab culture's traditional ideology, which dominates even science (Abu Khalil, 1992). In addition, there are the political conflicts in the Middle Eastern cultural context such as what is happening in Iraq (Harff, 2018). Thus, it is important to include such aspects in future researches.

\section{References}

AbuKhalil, A. (1992), "A new arab ideology?: the rejuvenation of Arab nationalism", The Middle East Journal, pp. 22-36.

Al Halbusi, H.A., Ismail, M.N. and Omar, S. (2019a), "Examining the impact of ethical leadership on employees' ethical behavior: the role of organizational justice and employees' moral identity", Journal of Technology Management and Business, Vol. 6 No. 2, pp. 30-48.

Al halbusi, H. and Amir Hammad Hamid, F. (2018), "Antecedents influence turnover intention: theory extension”, Journal of Organizational Behavior Research, Vol. 3 No. 2, pp. 287-304.

Al Halbusi, H. and Tehseen, S. (2017), "Corporate social responsibility (CSR): a literature review", Malaysian Journal of Business and Economics, Vol. 4 No. 2, pp. 30-48.

Al Halbusi, H., Tehseen, S. and Ramayah, T.C. (2017), "The impact of organizational justice on the ethical leadership under the moderating influence of perceived support: a conceptual study", Malaysian Journal of Business and Economics, Vol. 4 No. 1, pp. 46-64.

Al Halbusi, H., Williams, K.A., Mansoor, H.O., Hassan, M.S. and Hamid, F.A.H. (2019b), "Examining the impact of ethical leadership and organizational justice on employees' ethical behavior: does person-organization fit play a role?", Ethics and Behavior, pp. 1-19.

Anderson, J.C. and Gerbing, D.W. (1988), "Structural equation modeling in practice: a review and recommended two-step approach", Psychological Bulletin, Vol. 103 No. 3, p. 411.

Aryati, A.S., Sudiro, A., Hadiwidjaja, D. and Noermijati, N. (2018), "The influence of ethical leadership to deviant workplace behavior mediated by ethical climate and organizational commitment", International Journal of Law and Management, Vol. 60 No. 2, pp. 233-249.

Bandura, A. (1986), Social Foundations of Thought and Action: A Social Cognitive Theory, PrenticeHall, Englewood Cliffs, NJ.

Bandura, A. and Walters, R.H. (1977), Social Learning Theory, Prentice-hall, Englewood Cliffs, NJ, Vol. 1.

Baron, R.M. and Kenny, D.A. (1986), "The moderator-mediator variable distinction in social psychological research: conceptual, strategic, and statistical considerations", Journal of Personality and Social Psychology, Vol. 51 No. 6, p. 1173. 
Bell, M.L., Hobbs, B.F. and Ellis, H. (2003), "The use of multi-criteria decision-making methods in the integrated assessment of climate change: implications for IA practitioners", Socio-Economic Planning Sciences, Vol. 37 No. 4, pp. 289-316.

Blau, P. (1964), Exchange and Power in Social Life, Wiley, New York.

Boxx, W.R., Odom, R.Y. and Dunn, M.G. (1991), "Organizational values and value congruency and their impact on satisfaction, commitment, and cohesion: an empirical examination within the public sector", Public Personnel Management, Vol. 20 No. 2, pp. 195-205.

Bright, D.S., Winn, B.A. and Kanov, J. (2014), "Reconsidering virtue: differences of perspective in virtue ethics and the positive social sciences", Journal of Business Ethics, Vol. 119 No. 4, pp. $445-460$.

Brislin, R.W. (1980), "Translation and content analysis of oral and written materials", in Triandis, H.C. and Berry, J.W. (Eds), Handbook of Cross-Cultural Psychology: Methodology, Allyn and Bacon, Boston, pp. 389-444.

Brown, M.E. and Treviño, L.K. (2006), "Ethical leadership: a review and future directions", The Leadership Quarterly, Vol. 17 No. 6, pp. 595-616.

Brown, M.E. and Treviño, L.K. (2014), "Do role models matter? An investigation of role modeling as an antecedent of perceived ethical leadership", Journal of Business Ethics, Vol. 122 No. 4, pp. 587-598.

Brown, M.E., Treviño, L.K. and Harrison, D.A. (2005), "Ethical leadership: a social learning perspective for construct development and testing", Organizational Behavior and Human Decision Processes, Vol. 97 No. 2, pp. 117-134.

Cable, D.M. and Judge, T.A. (1996), "Person-organization fit, job choice decisions, and organizational entry”, Organizational Behavior and Human Decision Processes, Vol. 67 No. 3, pp. 294-311.

Chatman, J.A. (1989), "Improving interactional organizational research: a model of person-organization fit”, Academy of Management Review, Vol. 14 No. 3, pp. 333-349.

Chatman, J.A. (1991), "Matching people and organizations: Selection and socialization in public accounting firms", Administrative Science Quarterly, Vol. 36, pp. 459-484.

Chin, W.W. (1998), "Issues and opinion on structural equation modeling", MIS Quarterly, Vol. 22 No. 1 , pp. 7-16.

Chin, W.W. (1998), The Partial Least Squares Approach to Structural Equation Modeling, Lawrence Erlbaum, New Jersey, NJ, pp. 295-358.

Choi, S.B., Ullah, S. and Kwak, W.J. (2015), "Ethical leadership and followers' attitudes toward corporate social responsibility: the role of perceived ethical work climate", Social Behavior and Personality: An International Journal, Vol. 43 No. 3, pp. 353-365.

Cohen, J. (1988), Statistical Power Analysis for the Behavioral Sciences, 2nd ed. Routledge, New York, NY.

Dawson, J.F. (2014), "Moderation in management research: what, why, when, and how", Journal of Business and Psychology, Vol. 29 No. 1, pp. 1-19.

De Hoogh, A.H. and Den Hartog, D.N. (2008), "Ethical and despotic leadership, relationships with leader's social responsibility, top management team effectiveness and subordinates' optimism: a multi-method study", The Leadership Quarterly, Vol. 19 No. 3, pp. 297-311.

Decoster, S., Stouten, J. and Tripp, T.M. (2019), "When employees retaliate against self-serving leaders: the influence of the ethical climate", Journal of Business Ethics, pp. 1-19.

Demirtas, O. (2015), "Ethical leadership influence at organizations: evidence from the field", Journal of Business Ethics, Vol. 126 No. 2, pp. 273-284.

Demirtas, O. and Akdogan, A.A. (2015), "The effect of ethical leadership behavior on ethical climate, turnover intention, and affective commitment", Journal of Business Ethics, Vol. 130 No. 1, pp. 59-67.

Deshpande, S.P. and Joseph, J. (2009), "Impact of emotional intelligence, ethical climate, and behavior of peers on ethical behavior of nurses", Journal of Business Ethics, Vol. 85 No. 3, p. 403. 
Dickson, M.W., Smith, D.B., Grojean, M.W. and Ehrhart, M. (2001), "An organizational climate regarding ethics: the outcome of leader values and the practices that reflect them", The Leadership Quarterly, Vol. 12 No. 2, pp. 197-217.

Dimitriou, C.K. and Ducette, J.P. (2018), "An analysis of the key determinants of hotel employees' ethical behavior", Journal of Hospitality and Tourism Management, Vol. 34, pp. 66-74.

Duh, M., Belak, J. and Milfelner, B. (2010), "Core values, culture and ethical climate as constitutional elements of ethical behaviour: Exploring differences between family and non-family enterprises”, Journal of Business Ethics, Vol. 97 No. 3, pp. 473-489.

Elango, B., Paul, K., Kundu, S.K. and Paudel, S.K. (2010), "Organizational ethics, individual ethics, and ethical intentions in international decision-making", Journal of Business Ethics, Vol. 97 No. 4, pp. 543-561.

Elçi, M. and Alpkan, L. (2009), "The impact of perceived organizational ethical climate on work satisfaction", Journal of Business Ethics, Vol. 84 No. 3, pp. 297-311.

Engelbrecht, A.S., Van Aswegen, A.S. and Theron, C.C. (2005), "The effect of ethical values on transformational leadership and ethical climate in organizations", South African Journal of Business Management, Vol. 36 No. 2, pp. 19-26.

Engelbrecht, A.S., Wolmarans, J. and Mahembe, B. (2017), "Effect of ethical leadership and climate on effectiveness", SA Journal of Human Resource Management, Vol. 15 No. 1, pp. 1-8.

Ferrell, O.C., Fraedrich, J. and Ferrell, L. (2000), Business Ethics: Ethical Decision Making and Cases, 4 th ed., Houghton Mifflin Inc, New York, NY.

Festinger, L. (1957), A Theory of Cognitive Dissonance, Stanford university press, Vol. 2.

Fornell, C. and Cha, J. (1994), "Partial least squares", in Bagozzi, R.P. (Ed.), Advanced Methods in Marketing Research, Blackwell, Cambridge, pp. 52-78.

Gefen, D. and Rigdon, E.E. (2011), "An update and extension to SEM guidelines for administrative and social science research", MIS Quarterly, Vol. 35 No. 2, pp. 1-7.

Gouldner, A.W. (1960), "The norm of reciprocity: a preliminary statement", American Sociological Review, Vol. 25 No. 2, pp. 161-178.

Hair, J.F., Black, W.C., Babin, B.J. and Anderson, R.E. (2010), Multivariate Data Analysis, 7th ed., Pearson, New York, NY.

Hair, J.F., Hult, G.T.M., Ringle, C. and Sarstedt, M. (2017), A Primeron Partial Least Squares Structural Equation Modeling (PLS-SEM), Seconded, SAGE, London: Thousand Oaks.

Harff, B. (2018), Ethnic Conflict in World Politics, Routledge.

Henseler, J., Ringle, C.M. and Sarstedt, M. (2015), “A new criterion for assessing discriminant validity in variance-based structural equation modeling", Journal of the Academy of Marketing Science, Vol. 43 No. 1, pp. 115-135.

Jahantigh, M., Zare, S. and Shahrakipour, M. (2016), "The survey of the relationship between ethical climate and ethical behavior in nurses", Der Pharma Chemica, Vol. 8 No. 3, pp. 189-193.

Jaramillo, F., Mulki, J.P. and Marshall, G.W. (2005), "A meta-analysis of the relationship between organizational commitment and salesperson job performance: 25 years of research", Journal of Business Research, Vol. 58 No. 6, pp. 705-714.

Kang, D.S., Stewart, J. and Kim, H. (2011), "The effects of perceived external prestige, ethical organizational climate, and leader-member exchange (LMX) quality on employees' commitments and their subsequent attitudes", Personnel Review, Vol. 40 No. 6, pp. 761-784.

Khalil, S. (2016), "The reality of the institutes system in Iraq", Rawabet Center for Research and Strategic Studies, available at: http://rawabetcenter.com/en/?p=1434.

Khuntia, R. and Suar, D. (2004), "A scale to assess ethical leadership of Indian private and public sector managers", Journal of Business Ethics, Vol. 49 No. 1, pp. 13-26.

Kish-Gephart, J.J., Harrison, D.A. and Treviño, L.K. (2010), "Bad apples, bad cases, and bad barrels: meta-analytic evidence about sources of unethical decisions at work", Journal of Applied Psychology, Vol. 95 No. 1, p. 1. 
Kline, R.B. (2010), Principles and Practice of Structural Equation Modeling, 3rd ed., The Guilford Press, New York, NY.

Kristof, A.L. (1996), "Person-organization fit: an integrative review of its conceptualizations, measurement, and implications", Personnel Psychology, Vol. 49 No. 1, pp. 1-49.

Kristof-Brown, A.L., Zimmerman, R.D. and Johnson, E.C. (2005), "Consequences of individuals' fit at work: a meta-analysis of person-job, person-organization, person-group, and personsupervisor fit”, Personnel Psychology, Vol. 58, pp. 281-342.

Lauver, K.J. and Kristof-Brown, A. (2001), "Distinguishing between employees' perceptions of person-job and person-organization fit", Journal of Vocational Behavior, Vol. 59 No. 3, pp. 454-470.

Liedtka, J.M. (1989), "Value congruence: the interplay of individual and organizational value systems", Journal of Business Ethics, Vol. 8 No. 10, pp. 805-815.

Lin, C.P., Liu, N.T., Chiu, C.K., Chen, K.J. and Lin, N.C. (2019), "Modeling team performance from the perspective of politics and ethical leadership", Personnel Review, Vol. 48 No. 5, pp. 1357-1380.

Lu, C.S. and Lin, C.C. (2014), "The effects of ethical leadership and ethical climate on employee ethical behavior in the international port context", Journal of Business Ethics, Vol. 124 No. 2, pp. 209-223.

Luria, G. and Yagil, D. (2008), "Procedural justice, ethical climate and service outcomes in restaurants", International Journal of Hospitality Management, Vol. 27 No. 2, pp. 276-283.

Manz, C.C., Anand, V., Joshi, M. and Manz, K.P. (2008), "Emerging paradoxes in executive leadership: a theoretical interpretation of the tensions between corruption and virtuous values", The Leadership Quarterly, Vol. 19 No. 3, pp. 385-392.

Mayer, D.M., Kuenzi, M., Greenbaum, R., Bardes, M. and Salvador, R.B. (2009), "How low does ethical leadership flow? Test of a trickle-down model”, Organizational Behavior and Human Decision Processes, Vol. 108 No. 1, pp. 1-13.

McCulloch, M.C. and Turban, D.B. (2007), "Using person-organization fit to select employees for highturnover jobs", International Journal of Selection and Assessment, Vol. 15 No. 1, pp. 63-71.

Meglino, B.M., Ravlin, E.C. and Adkins, C.L. (1989), “A work values approach to corporate culture: a field test of the value congruence process and its relationship to individual outcomes", Journal of Applied Psychology, Vol. 74 No. 3, p. 424.

Mehta, S.N. (2003), "MCI: is being good good enough?", Fortune, Vol. 148 No. 9, pp. 117-117.

Memon, M.A., Ting, H., Ramayah, T., Chuah, F. and Cheah, J.H. (2017), "A review of the methodological misconceptions and guidelines related to the application of structural equation modeling: a Malaysian scenario", Journal of Applied Structural Equation Modeling, Vol. 1 No. 1, pp. 1-13.

Meyer, M., Sison, A.J.G. and Ferrero, I. (2019), "How positive and Neo-Aristotelian leadership can contribute to ethical leadership", Canadian Journal of Administrative Sciences/Revue Canadienne des Sciences de l'Administration, Vol. 36 No. 3, pp. 390-403.

Moaddel, M. and Karabenik, S.A. (2010), "Religious fundamentalism in eight muslim-majority countries: reconceptualization and assessment”, Journal for the Scientific Study of Religion, Vol. 57 No. 4, pp. 676-706.

Moore, C., Mayer, D.M., Chiang, F.F., Crossley, C., Karlesky, M.J. and Birtch, T.A. (2019), "Leaders matter morally: the role of ethical leadership in shaping employee moral cognition and misconduct", Journal of Applied Psychology, Vol. 104 No. 1, p. 123.

Neubert, M.J., Carlson, D.S., Kacmar, K.M., Roberts, J.A. and Chonko, L.B. (2009), "The virtuous influence of ethical leadership behavior: evidence from the field", Journal of Business Ethics, Vol. 90 No. 2, pp. 157-170.

Neves, P., Almeida, P. and Velez, M.J. (2018), "Reducing intentions to resist future change: combined effects of commitment-based HR practices and ethical leadership", Human Resource Management, Vol. 57 No. 1, pp. 249-261. 
Newman, A., Allen, B. and Miao, Q. (2015), "I can see clearly now: the moderating effects of role clarity on subordinate responses to ethical leadership", Personnel Review, Vol. 44 No. 4, pp. 611-628.

Nunnally, J.C. and Bernstein, I.H. (1994), Psychometric Theory, McGraw-Hill, New York, NY.

Linking ethical leadership and ethical climate

O’Reilly, C.A., III, Chatman, J. and Caldwell, D.F. (1991), "People and organizational culture: a profile comparison approach to assessing person-organization fit", Academy of Management Journal, Vol. 34 No. 3, pp. 487-516.

Ofori, G. (2009), "Ethical leadership: examining the relationships with full range leadership model, employee outcomes, and organizational culture”, Journal of Business Ethics, Vol. 90 No. 4, p. 533.

Padilla, A., Hogan, R. and Kaiser, R.B. (2007), "The toxic triangle: destructive leaders, susceptible followers, and conducive environments", The Leadership Quarterly, Vol. 18 No. 3, pp. 176-194.

Podsakoff, P.M., MacKenzie, S.B., Lee, J.Y. and Podsakoff, N.P. (2003), "Common method biases in behavioral research: a critical review of the literature and recommended remedies", Journal of Applied Psychology, Vol. 88 No. 5, p. 879.

Podsakoff, P.M., MacKenzie, S.B. and Podsakoff, N.P. (2012), "Sources of method bias in social science research and recommendations on how to control it", Annual Review of Psychology, Vol. 63, pp. 539-569.

Preacher, K.J. and Hayes, A. F. (2004), "SPSS and SAS procedures for estimating indirect effects in simple mediation models", Behavior Research Methods, Instruments, and Computers, Vol. 36 No. 4, pp. 717-731.

Preacher, K. and Hayes, A. (2008), "Asymptotic and resampling strategies for assessing and comparing indirect effects in multiple mediator models", Behaviour Research Methods, Vol. 40, pp. 879-891, The Sage Handbook Of Advanced Data Analysis Methods For Communication Research, 1354.

Presbitero, A. and Teng-Calleja, M. (2019), "Ethical leadership, team leader's cultural intelligence and ethical behavior of team members", Personnel Review.

Ribberink, E., Achterberg, P. and Houtman, D. (2018), "Religious polarization: contesting religion in secularized Western European countries", Journal of Contemporary Religion, Vol. 33 No. 2, pp. 209-227.

Ringle, C.M., Wende, S. and Becker, J.-M., (2015), SmartPLS 3. Bonningstedt: SmartPLS, available at: http://www.smartpls.com (accessed 30 December 2018).

Ruiz-Palomino, P., Martínez-Cañas, R. and Fontrodona, J. (2013), "Ethical culture and employee outcomes: The mediating role of person-organization fit", Journal of Business Ethics, Vol. 116 No. 1, pp. 173-188.

Ruiz-Palomino, P., Ruiz-Amaya, C. and Knörr, H. (2011), "Employee organizational citizenship behaviour: The direct and indirect impact of ethical leadership", Canadian Journal of Administrative Sciences/Revue Canadienne des Sciences de l'Administration, Vol. 28 No. 3, pp. 244-258.

Schaubroeck, J., Walumbwa, F. O., Ganster, D.C. and Kepes, S. (2007), "Destructive leader traits and the neutralizing influence of an 'enriched' job", The Leadership Quarterly, Vol. 18 No. 3, pp. 236-251.

Schminke, M., Ambrose, M.L. and Neubaum, D.O. (2005), "The effect of leader moral development on ethical climate and employee attitudes", Organizational Behavior and Human Decision Processes, Vol. 97 No. 2, pp. 135-151.

Stead, W.E., Worrell, D.L. and Stead, J.G. (1990), “An integrative model for understanding and managing ethical behavior in business organizations”, Journal of Business Ethics, Vol. 9 No. 3, pp. 233-242.

Sullivan, G.M. and Feinn, R. (2012), "Using effect size — or why the P value is not enough", Journal of Graduate Medical Education, Vol. 4 No. 3, pp. 279-282. 
Terborg, J.R. (1981), "Interactional psychology and research on human behavior in organizations", Academy of Management Review, Vol. 6 No. 4, pp. 569-576.

Treviño, L.K. and Brown, M.E. (2004), "Managing to be ethical: Debunking five business ethics myths", Academy of Management Perspectives, Vol. 18 No. 2, pp. 69-81.

Treviño, L.K., Butterfield, K.D. and McCabe, D.L. (1998), "The ethical context in organizations: influences on employee attitudes and behaviors", Business Ethics Quarterly, Vol. 8 No. 3, pp. 447-476.

Treviño, L.K., Hartman, L.P. and Brown, M. (2000), "Moral person and moral manager: how executives develop a reputation for ethical leadership", California Management Review, Vol. 42 No. 4, pp. 128-142.

Treviño, L.K., Den Nieuwenboer, N.A. and Kish-Gephart, J.J. (2014), “(Un) ethical behavior in organizations", Annual Review of Psychology, Vol. 65, pp. 635-660.

Triandis, H.C., Bontempo, R., Villareal, M.J., Asai, M. and Lucca, N. (1988), "Individualism and collectivism: cross-cultural perspective on self-ingroup relationships", Journal of Personality and Social Psychology, Vol. 54, pp. 323-338.

Valentine, S., Godkin, L. and Lucero, M. (2002), "Ethical context, organizational commitment, and person-organization fit", Journal of Business Ethics, Vol. 41 No. 4, pp. 349-360.

Van Vianen, A. (2001), "Person-organization fit: the match between theory and methodology: Introduction to the special issue", Applied Psychology, Vol. 50 No. 1, pp. 1-4.

Van Wyk, C. (1989), "The human resource practitioner's changing role”, IPB Journal, Vol. 7, pp. 10-14.

Verquer, M.L., Beehr, T.A. and Wagner, S.H. (2003), "A meta-analysis of relations between person-organization fit and work attitudes", Journal of Vocational Behavior, Vol. 63 No. 3, pp. 473-489.

Vilela, B.B., González, J.A.V. and Ferrín, P.F. (2008), "Person-organization fit, OCB and performance appraisal: evidence from matched supervisor-salesperson data set in a Spanish context”, Industrial Marketing Management, Vol. 37 No. 8, pp. 1005-1019.

Victor, B. and Cullen, J.B. (1988), "The organizational bases of ethical work climates", Administrative Science Quarterly, pp. 101-125.

Weeks, W.A., Loe, T.W., Chonko, L.B. and Wakefield, K. (2004), "The effect of perceived ethical climate on the search for sales force excellence", Journal of Personal Selling \& Sales Management, Vol. 24 No. 3, pp. 199-214.

Whetten, D.A. (2009), "An examination of the interface between context and theory applied to the study of Chinese organizations", Management and Organization Review, Vol. 5 No. 1, pp. 29-55.

Woodrow, C. and Guest, D.E. (2014), "When good HR gets bad results: Exploring the challenge of HR implementation in the case of workplace bullying", Human Resource Management Journal, Vol. 24 No. 1, pp. 38-56.

Yukl, G. (2010), Leadership in Organizations, 7th ed., Pearson Prentice Hall, Upper Saddle River, NJ.

Yun, S., Cox, J. and Sims, H.P., Jr (2006), "The forgotten follower: a contingency model of leadership and follower self-leadership", Journal of Managerial Psychology, Vol. 21 No. 4, pp. 374-388.

Zehir, C. and Erdogan, E. (2011), "The association between organizational silence and ethical leadership through employee performance", Procedia-Social and Behavioral Sciences, Vol. 24, pp. 1389-1404.

\section{Further reading}

Salin, D. (2009), "Organisational responses to workplace harassment: an exploratory study", Personnel Review, Vol. 38 No. 1, pp. 26-44. 
Sims, R.L. and Keon, T.L. (2000), "The influence of organizational expectations on ethical decisionmaking conflict", Journal of Business Ethics, Vol. 23 No. 2, pp. 219-228.

Vlachos, P.A., Panagopoulos, N.G. and Rapp, A.A. (2014), "Employee judgments of and behaviors toward corporate social responsibility: a multi-study investigation of direct, cascading, and moderating effects", Journal of Organizational Behavior, Vol. 35 No. 7, pp. 990-1017.

Linking ethical leadership and ethical climate

\section{Corresponding author}

Hussam Al Halbusi can be contacted at: hussam.mba@gmail.com

For instructions on how to order reprints of this article, please visit our website:

www.emeraldgrouppublishing.com/licensing/reprints.htm

Or contact us for further details: permissions@emeraldinsight.com 